\title{
Critical Thinking Skills of Prospective Elementary School Teachers in Integrated Science-Mathematics Lectures
}

\author{
Yanti Fitria, Fiddinya Nurul Hasanah, Nurhizrah Gistituati \\ Study Program of Primary Education, University Negeri Padang, Padang, Indonesia
}

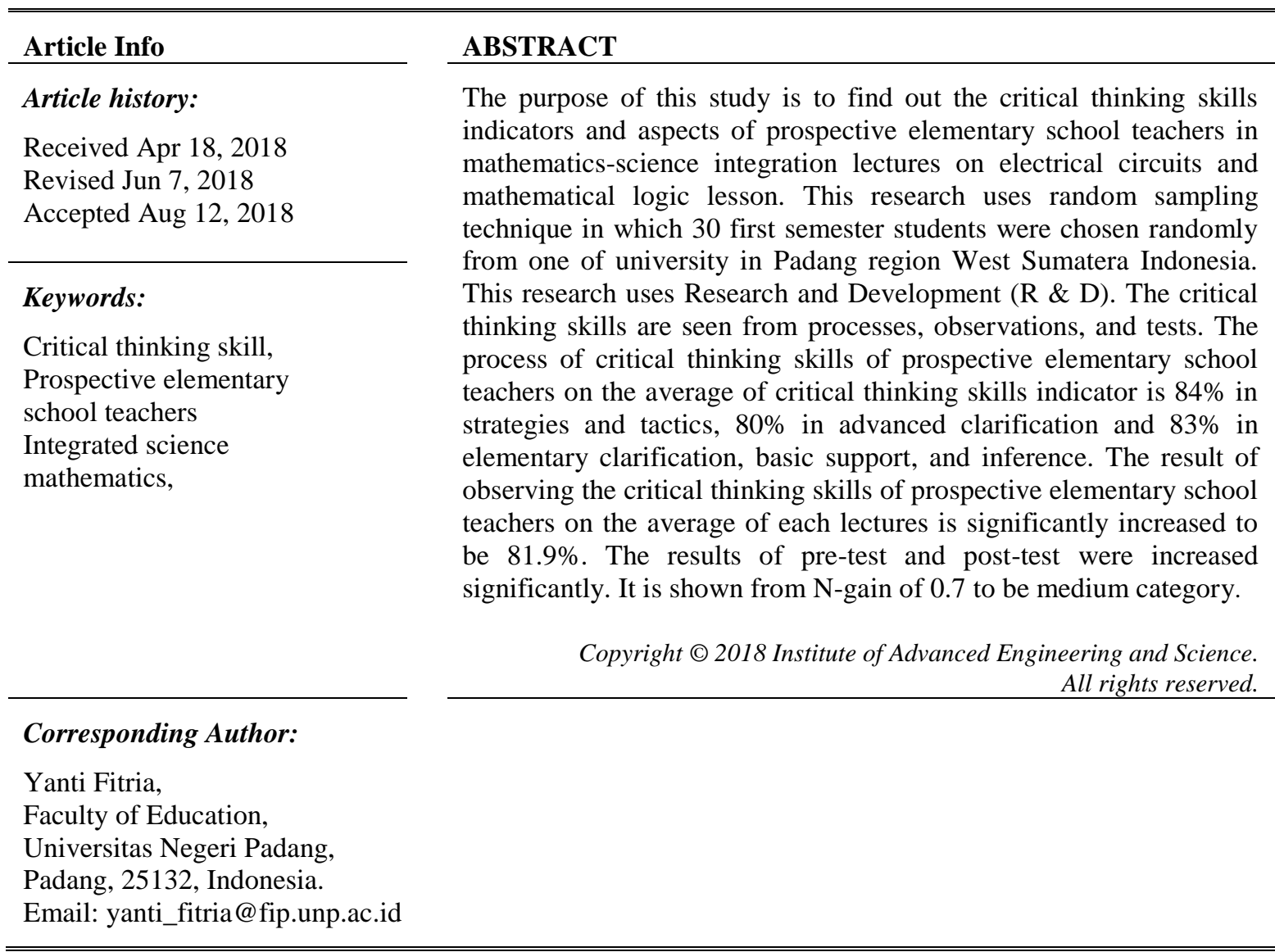

\section{INTRODUCTION}

The development of knowledge and the demands of the working space must be followed by the development of the abilities and skills of college students as future teachers. One of the efforts that can be done to develop the college students' skill and abilities is by integrating one discipline with other disciplines. This attempt is expected to develop the profundity of the content and the relationship between these disciplines. In addition, this effort is also expected to train the students' skills as prospective elementary school teachers in developing a lesson. Collins suggests that the integrated learning will occur if a reasonable occurrence exist or a topic is explored. By actively participating in the exploration, the students will learn the teaching materials and the learning process of several fields in the same learning process. Further, it is stated that integrated learning as a process has several characteristics namely: holistic, meaningful, authentic, and active. The integrated learning begins by identifying concepts, skills, attitudes that are overlapping in several disciplines or several fields of study [1]. In general, the basic disciplines of primary education like science and mathematics are two areas that are allied and interrelated. The integrated science and mathematics have long been a highlight in the educational field. The development of science, mathematics, and technology in the 21 st century are factors that triggers the existence of integrated science and mathematics. Many studies have been conducted in the term of the integration of the two disciplines. This condition is expected to improve the development of knowledge, skills, and the quality of education. This is in harmony who states 
that the integration of these two disciplines in a lesson will enhance and broaden the subject of both disciplines. In addition, the two disciplines can complement each other [1].

Science is a part of knowledge that understands the system of nature and part of a self-contained science that continues to be explored and improved [2]. Mathematics allows the students to acquire the skills to analyze various problems or situations, anticipate, plan, make decisions, and solve problems. Mathematics is served as a tool for learning science, technology and other disciplines [3]. Proposes a pattern of integrating science and mathematics with five different principles of integration: (1) Sequence integration pattern: involves the study of science and mathematics sequentially; (2) Partial integration pattern: involves incorporated and separate learning from science and mathematics; (3) Pattern of stratified integration: the use of one of the disciplines as the main and other disciplines as a supporter; (4) The pattern of total integration: integrates concepts of science and mathematics simultaneously; (5) Pattern of parallel integration: separates but simultaneous learning with science and math [1]. The principles developed by Hurley are used to put forward the principle of integrated learning independently that every principle emphasizes different ways.

The learning process that utilizes the integration of mathematical and science for the students as prospective elementary school teachers is necessary. Integrated science in learning is necessary for teachers to plan, design and implement the learning process absolutely [4-5]. The integration can provide a significant effect in improving the critical thinking skills of the learners [6]. The integration of science and mathematics provides an opportunity for the students to apply real disciplines in relevant situations from different perspectives [7]. This is done in order to develop the skills and abilities of the students in developing the two disciplines in an integrated manner, so that the thinking patterns of the students as prospective elementary school teachers are accustomed to integrate two disciplines. Another advantage of the integration of mathematics and science is that the experience gained by the learners improves their critical thinking skills, creative thinking, and higher-order thinking. Nickerson blames that thinking skills include problem solving skills, decision making, critical thinking, logical thinking, and creative thinking [8-10].

One of the thinking skills that plays an important role in human success in life is critical thinking. Critical thinking means the way of thinking in a certain quality that is basically a good thought and it meets to the criteria or standards of adequacy and accuracy of predefined standards of thought. Sternberg explains that critical thinking is a process of mental organizing and strategy that used to represent problem solving, decision making, and learning new concepts [11]. More specifically, critical thinking is a process for analyzing arguments, claims, or evidence to create an accurate decision [12]. Therefore, critical thinking skills are needed to understand an information that will be used to move an idea [13]. According to Scriven, critical thinking skills are positioned as skilled and active in interpretation, evaluation of observation, communication, and argument [14].

Critical thinking is not a skill that humans gain since they were born. Critical thinking skills should be trained in the learning process. The aspects of critical thinking skills are classified into five: Elementary clarification, Basic support, Inference, Advanced clarification, and Strategies and tactics. Ennis describes each aspects as follow: (1) Elementary clarification includes focusing questions, analyzing arguments, asking questions and answering questions that require explanations or challenges; (2) Basic support (basic skills) includes considering the credibility of the source and making observation considerations; (3) Inference includes composing and considering deduction, composing and considering induction, making decisions and considering the outcome; (4) Advanced clarification (provides further explanation) includes identifying terms and considering definitions, identifying assumptions; (5) Strategies and tactics includes determining an action and interacting with others $[11,15-16]$.

The college students as prospective elementary school teachers will play an important role in making judgments, teaching and developing students' critical thinking skills [17-18]. The roles of prospective elementary school teachers are to guide, coordinate, help, and encourage their students to be critical and creative [19]. However, what happened in the reality is that the critical thinking of the prospective elementary school teachers has not shown to be optimal yet. This condition was seen while the writers were making observations such as the student has not been able to determine the interrelation of heat material in everyday life. This case can be seen when the lecturer gave question to the students to connect the occurrence of heat in everyday life, but the student got difficulties to answer. Then, the students had difficulty in determining conclusions and giving opinions. It was shown when the lecturer appointed one of the students to deduce the material that has been discussed. The student smoothly explained the conclusions of the material, but the explanation is not based on the conclusions of the material nor based on the results of his own thoughts. Next, when the lecturer gave a problem, the students were still confused in determining the cause of the problem.

The integration of science and mathematics has been becoming necessary to be implemented so that the students' thinking skills become strong. The college students as prospective elementary school teachers will be encouraged to add their insight into the material discussed and to relate it to the real life condition.

EduLearn Vol. 12, No. 4, November 2018 : 597 - 603 
The study of electrical circuits and mathematical logic are designed in science and mathematics integration lectures for the students of primary teacher education. As the beginning of the learning process, the students were given the problem and asked to use the knowledge of science that integrated with mathematics. The application of the integration of science and mathematics lectures is expected to attract the students' willingness, arouse the passion, and give motivation to the students.

\section{RESEARCH METHOD}

This study used Research and Development ( R \& D) research method. The objective of the research was to know the critical thinking skills of prospective elementary school teachers. The critical thinking skills were encompassed through the observation of lecturing and test sheets given before and after the lecture. The test instrument of critical thinking skills had been tested first before it was used to see the validity and reliability of the questions to the 3rd semester students of primary teacher education program in one of the Higher Education Institute of Teacher Training in Padang. Data analysis of the achievement of students' critical thinking skills was carried out using descriptive statistics is percentage techniques. Normalized gain calculation to see student learning progress. The research was conducted three times to the first semester students of the primary of teacher education in one of the Higher Education Institute of Teacher Training in Padang. The subject matter of this research was on the material of electrical circuits and mathematical logic in science lectures that integrated with mathematics.

\section{RESULTS AND ANALYSIS}

The observation on the students' critical thinking skills as prospective elementary school teachers was conducted in 2 ways that were an observation and a test. The observation of the process was seen from the way of completion of the exercise questions undertaken by the students in every meeting. The results of the observations were seen based on each meeting. Test results were seen from the pre test and post test critical thinking skills.

\subsection{The Process of Critical Thinking Skills}

The process of critical thinking skills is focused to see the way of thinking of the college students as prospective elementary school teachers during the lecture process. The process focused on five indicators of critical thinking skills proposed [16]. The result of the process was obtained through the exercises given during the mathematics and science integration lectures. It was conducted on the first semester students of primary teacher education in one of the university in Padang. The data of the critical students' skill thinking process as prospective elementary school teacher is shown in Figure 1. The highest indicator of critical thinking skill is strategies and tactics that reached $84 \%$. The low critical thinking skill indicator is advanced clarification that reached only $80 \%$. On indicators of critical thinking skills provide a elementary clarification, basic support, and inference is $83 \%$. The following process of critical thinking skills per indicator can be seen in Figure 1.

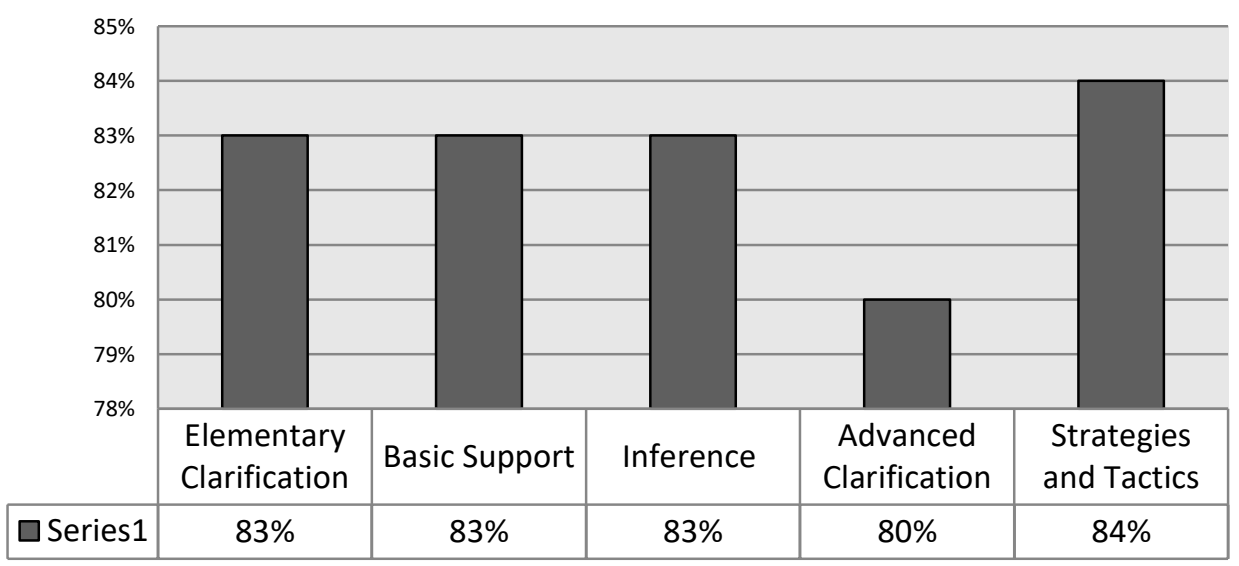

Figure 1. The Results of the Student Critical Thinking Skills Process per Indicator 


\subsection{The Results of the Critical Thinking Skills Observation}

The observations focused on five indicators of critical thinking skills proposed [16], which are outlined into six observed aspects, presented in Table 1.

Table 1. Aspects Observed in Critical Thinking Skills

\begin{tabular}{ll}
\hline \multicolumn{1}{c}{ Critical Thinking Skill Indicators } & \multicolumn{1}{c}{ Aspects observed } \\
\hline Elementary Clarification & 1. Responding to lecturers' questions \\
Basic Support & 2. Report the results of observation \\
Inference & 3. Make problem solutions \\
& 4. Drawing conclusions as facts \\
Advanced Clarification & 5. Identify unclear assumptions or states \\
Strategies and Tactics & 6. Review the results of the practicum that has been done \\
\hline
\end{tabular}

The observation result of the students' critical thinking skills for each aspects is shown in Figure 2. Based on the data in the diagram, it shows that reporting the observation result and making solution of the problem attracted the lowest score $(80 \%)$. The highest score $(86 \%)$ is drawing conclusions. Identifying an unclear or expressed assumption is $81 \%$. Responding to lecturers' questions and reviewing the results of the experiments done $82 \%$. The aspect of drawing conclusions is considered to be difficult by the students as prospective elementary school teachers since they got the lowest score. This difficulty is because there are still some of the students who are shy to express their opinions. Thus, the average of all aspects of each meeting observed was $81.9 \%$. The result of critical thinking skills observation on each aspect can be seen in Figure 2.

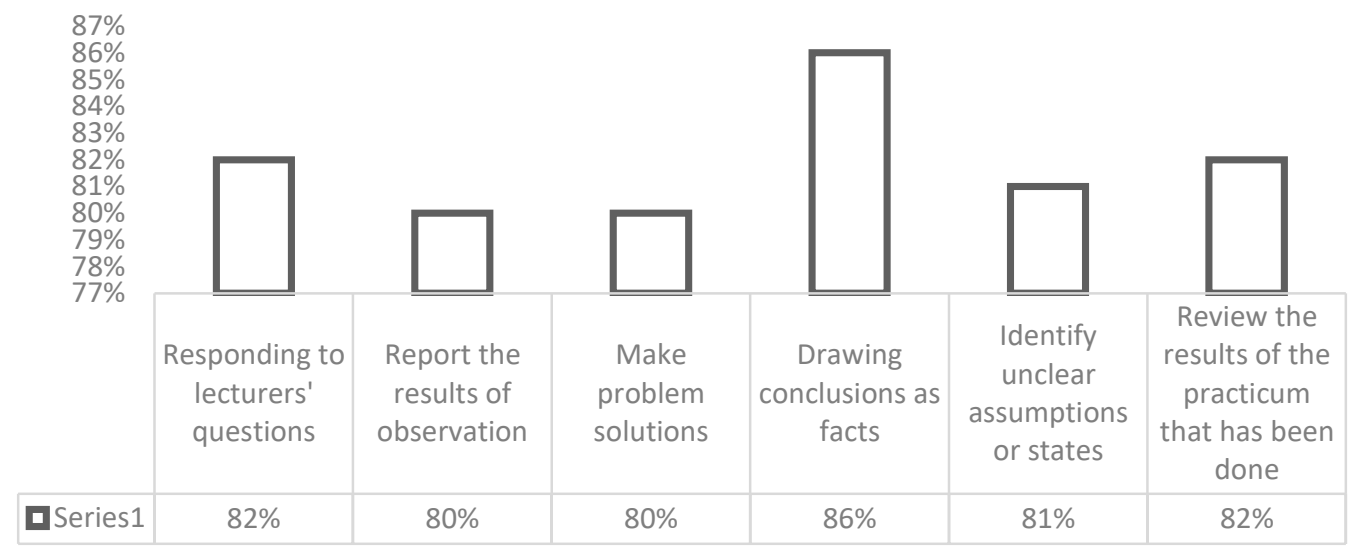

Figure 2. Results of Student Critical Thinking Skills Observation Per Aspect

\subsection{The Results of the Critical Thinking Skills Observation}

\subsubsection{The Validation of Critical Thinking Skills Tests}

The critical thinking skills are also seen from pre test and post test. Before the test questions used for the test, it had been firstly validated by experts. The character of the question is valid if it reflects the soul of knowledge and its language is easily to be understood [20]. The validation result of the critical thinking skills test as a whole is shown in Table 2.

Table 2. The Result of Critical Thinking Skills Test Validity by Experts.

\begin{tabular}{cccc}
\hline No & Experts & Average $(\%)$ & Category \\
\hline 1 & Material & $93 \%$ & Highly valid \\
2 & Language & $95 \%$ & Highly valid \\
\hline
\end{tabular}

The validity results shown in Table 2 above indicates that the validation of the material aspects was on average score of $93 \%$ and the language aspect was on average score of $95 \%$. This score was obtained from 
the expert judgment. The score analysis shows that the critical thinking skills test that had already been tested to the 3rd semester students of primary teacher education program in one of university in Padang considering its reliability of the problem, the level of difficulty of each problem, and the item category were valid. So that, the good questions could be chosen and used as instruments in the research.

\subsubsection{Reliability, Index of Difficulties, and Item Category of Critical Thinking Skills Tests}

The reliability is the consistency of measurement or stability of measurement instruments. An instrument is said to be reliable if the test is said to have a high reliability value, if the test made has consistent results in measuring the ability to be measured [21]. So, the reliability must be able to produce the actual information. The index of difficulty is only the percentage of the students in answering the test questions correctly. The higher percentage of the difficult index is, the question will be easier [22]. Then, the test of the study result can be said to either be in moderate difficulty level or enough. The item category is the ability of a problem to distinguish between high-ability students with low-ability students [23]. Here is a recapitulation of test results about thinking skills using ANATES V.4 program.

Table 3. The Recapitulation of Critical Thinking Skills Pre-Test Result

\begin{tabular}{ccccccc}
\hline \multirow{2}{*}{ Question } & \multicolumn{2}{c}{ Item category } & \multicolumn{2}{c}{ Difficulty index } & \multicolumn{2}{c}{ Reliability } \\
& $(\%)$ & Criteria & $(\%)$ & Criteria & Score & Criteria \\
\hline 1 & 40.63 & Good & 82.81 & Easy & & \\
2 & 56.25 & Good & 70.31 & Very Easy & & \\
3 & 21.88 & Fairly Good & 81.25 & Easy & & \\
4 & 43.75 & Good & 82.81 & Easy & & \multirow{2}{*}{ Average } \\
5 & 31.25 & Good & 81.25 & Easy & & \\
6 & 25.00 & Fairly Good & 84.38 & Easy & & \\
7 & 75.00 & Very Good & 65.63 & Fairly Easy & & \\
8 & 46.88 & Good & 65.63 & Fairly Easy & & \\
9 & 81.25 & Very Good & 70.31 & Very Easy & & \\
10 & 25.00 & Fairly Good & 84.38 & Easy & & \\
\hline
\end{tabular}

The analysis shows that the critical thinking skill test developed was good, accurate and could be used as a pre test and post test for the students in measuring the improvement of the students' critical thinking skills as shown in Table 3.

\subsubsection{The Result of Critical Thinking Skills Pre-Test and Post-Test}

The critical thinking skills test measured in this study focused on five indicators of critical thinking skills proposed [16]: (1) Elementary clarification; (2) Basic support; (3) inference; (4) Advanced clarification; (5) Strategies and tactics. The assessment in general could be seen in Table 4.

Table 4. The Average of Critical Thinking Skill Pre-Test and Post-Test Result

\begin{tabular}{ccc}
\hline Pre Test & Post Test & N-Gain \\
\hline 32,3 & 81,0 & 0,7 \\
\hline
\end{tabular}

Table 4 shows that the mean of pre-test value was 32.3 and the mean post-test value was 81.0 and the gain value was 0.7 with the moderate category. This data shows that the science lectures activities integrated with mathematics on electrical circuitry and mathematical logic were quite good to improve the students' critical thinking skills. The percentage of pre-test and post-test of the students' critical thinking skills based on critical thinking skill indicator could be seen in Figure 3 as follows.

Figure 4 shows that the mean percentage of each critical thinking skill indicators increased significantly. This data indicates that science activities integrated with mathematics on electrical circuitry and mathematical logic were able to improve the students' critical thinking skills. The students' critical thinking skills as prospective elementary school teachers may increase because the lectures that integrated mathematical and science in electrical circuitry and mathematical logic material helped the students to achieve their critical thinking skills. The students' critical thinking skill indicators which were elementary clarification, basic support, inference, advanced clarification, and strategies and tactics. Integrated science learning mathematics can improve critical thinking skills [9]. This result was supported by other research statements related to this research that had been conducted before by several researchers. They concluded that the concept of integrated learning has a significant effect on improving the students' critical thinking skills and problem solving in learning [6,24,25]. 


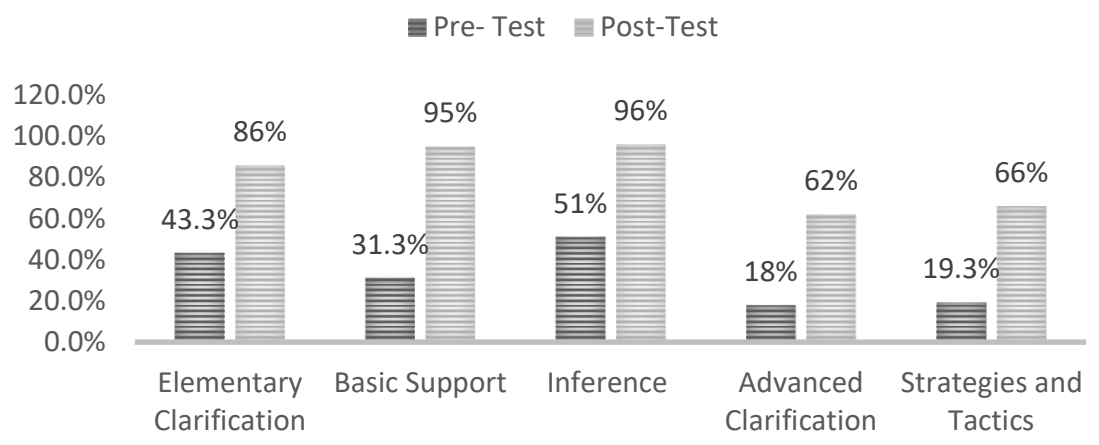

Figure 4. Mean Percentage of Pre-Test and Post-Test For Each Critical Thinking Skills Indicators

\section{CONCLUSION}

The result showed that the students' critical thinking skills as prospective elementary school teachers in science lectures that integrated with mathematics on electrical circuitry and mathematical logic were significantly improved. The process of the students' critical thinking skills as prospective elementary school teachers was assessed from the exercises given based on the critical thinking skills indicators. The highest critical thinking skill indicator was strategies and tactics that reached $84 \%$. The lowest critical thinking skill indicator was advanced clarification that reached $80 \%$. On the other hand, the other critical thinking skills indicators such as providing a elementary clarification, basic support, and inference reached $83 \%$. Thus, the observation result of critical thinking skill for each aspect like reporting the observation result and making problem solution were in the lowest $(80 \%)$. Meanwhile, the highest $(86 \%)$ was drawing conclusions. Identifying an unclear or expressed assumption was $81 \%$. Responding to lecturers' questions and reviewing the results of the experiments done were $82 \%$. There were differences on the students' critical thinking skills which were significant from the results of pre test and post test. In conclusion, the lectures of science that integrated with mathematics in electrical circuitry and mathematical logic were able to improve students' critical thinking skills (N-Gain 0.7).

\section{ACKNOWLEDGEMENTS}

The authors would like to express their gratitude to (1) The Head of research institute and community service, (2) The Dean of the faculty of education Universitas Negeri Padang for the collaboration and encouragement to do a collaborative research, (3) The hairman of the PGSD department.

\section{REFERENCES}

[1] Kibbe D L, Hackett J, Hurley M, McFarland A, Schubert K G, Schultz A and Harris S., "Ten Years of TAKE 10!®: Integrating physical activity with academic concepts in elementary school classrooms," Prev. Med, vol. 5, no. 2, pp. 43-50, 2011.

[2] Windschitl M, Thompson J and Braaten M., "Beyond the Scientific Method: Model-Based Inquiry as a New Paradigm of Preference for School Science Investigations," Sci. Educ. vol. 9, no. 2, pp. 941-67, 2008.

[3] Kaewsaiha C, Leelawatthanapan N, Bumrungpong P, Rungtrak T, Wangthaphun T, Thatho Y, Janjumpa C and Ohama P., "The Effect of Integrated Learning in Mathematics and Science on Student's Critical Thinking and Collaboration Skills," vol. 1, no. 1, pp. 1-10, 2012.

[4] Fitria, S., "Speaking Activities in Young Learners Classroom: The Implementation of Project-Based Learning Approach," J. English Educ, vol. 1, pp. 90-102, 2013.

[5] Yuca V., Daharnis R A and Ardi Z., "The Importance of Infrastructure Facilities," Statistics (Ber). 35 38, 2017.

[6] Kurt K and Pehlivan M., "Integrated Programs for Science and Mathematics: Review of Related Literature," Int. J. Educ. Math. Sci. Technol. vol. 1, 2013.

[7] Davison D. M, Miller K.W and Metheny D. L, "What Does Integration of Science and Mathematics Really Mean?," Sch. Sci. Math, vol. 9, no. 5, pp. 226-30, 1995.

[8] Furner J. M. and Kumar D. D, "The Mathematics and Science Integration Argument: A Stand for Teacher Education," Eurasia J. Math. Sci. Technol. Educ, vol. 3, 2007.

[9] Stohlmann M, Moore T J and Roehrig G. H, "Considerations for Teaching Integrated STEM Education," J. PreCollege Eng. Educ. Res. 2 4, 2012.

[10] Çekin A, "The Investigation of Critical Thinking Dispositions of Religious Culture and Ethics Teacher Candidates," J. Educ. Learn, vol. 9, pp. 158-64, 2015. 
[11] Lai E R, "Critical Thinking: A Literature Review," Pearson's Res. Reports, vol. 6, pp. 40-1, 2011.

[12] Paul R and Elder L, The Miniature Guide to Critical Thinking: Concepts \& Tools (Foundation for Critical Thinking Dillon Beach, CA), 2006.

[13] Firdaus F, Kailani I, Bakar M N Bin and Bakry B, "Developing Critical Thinking Skills of Students in Mathematics Learning, J. Educ. Learn, vol. 9, pp. 226-36, 2015.

[14] Adeyemi S. B, "Developing Critical Thinking Skills in Students: A Mandate for Higher Education in Nigeria," Eur. J. Educ. Res, vol. 1, pp. 155-61, 2012.

[15] Mabruroh F and Suhandi A, "Construction Of Critical Thinking Skills Test Instrument Related The Concept on Sound Wave," Journal of Physics: Conference Series, vol. 812, pp. 12056, 2017.

[16] Fahim M and Eslamdoost S, "Critical Thinking: Frameworks and Models for Teaching," English Lang. Teach, vol. 7, pp. 141, 2014.

[17] Dyson B, Vickers K, Turtle J, Cowan S and Tassone A, "Evaluating the use of Facebook to Increase Student Engagement and Understanding in Lecture-Based Classes," High. Educ, vol. 6, no. 9, 303-13, 2015.

[18] Hapsari S, "A Descriptive Study of the Critical Thinking Skills of Social Science at Junior High School," J. Educ. Learn, vol. 10, pp. 228-34, 2016.

[19] Giannoukos G and Besas G, "Adult Education and Learning Theories," Int. Lett. Soc. Humanist. Sci, vol. 60, pp. 34-8, 2015.

[20] Plomp T, Educational Design Research: An introduction, Educ. Des. Res, pp. 11-50, 2013.

[21] Drost E. A, "Validity and Reliability in Social Science Research," Educ. Res. Perspect, vo. 3, no. 8, pp. 105, 2011

[22] Alvehag K and Awodele K, "Impact of Reward and Penalty Scheme on the Incentives for Distribution System Reliability," IEEE Trans. Power Syst, vol. 2, no. 9, pp. 386-94, 2014.

[23] Syamsuddin I, "Fuzzy Multi Criteria Evaluation Framework for E-learning Software Quality," Acad. Res. Int, vol. 2, pp. 139-47, 2012.

[24] King K. P. and Wiseman D. L, "Comparing Science Efficacy Beliefs of Elementary Education Majors in Integrated and Non-Integrated Teacher Education Coursework," J. Sci. Teacher Educ, vol. 1, no. 2, pp. 143-53, 2001.

[25] Fllis A. K. and Fouts J. T, "Interdisciplinary Curriculum: The Research Base: The Decision to Approach Music Curriculum from an Interdisciplinary Perspective should Include a Consideration of all the Possible Benefits and Drawbacks," Music Educ. J, vol. 8, no. 7, pp. 22-68, 2001. 